\title{
MORTALITY FROM CEREBROVASCULAR ACCIDENTS AND HYPERTENSION IN THE REPUBLIC OF IRELAND
}

\author{
BY
}

\author{
ROY M. ACHESON*
}

From the Department of Social Medicine, Trinity College, Dublin

It is well known that hypertension may be associated with certain cerebrovascular accidents on the one hand, and with coronary heart disease on the other. The fact that two diseases tend to occur together in one patient, however, does not necessarily mean that they are similar in their epidemiology or mortality. A study of the mortality from coronary artery disease in the Republic of Ireland over the past 30 years has recently been published from this department (Acheson and Thornton, 1958), and it was felt that it might be instructive to undertake similar analyses of the vital statistics of the Republic for hypertension and cerebrovascular accidents and to compare them with those already published for coronary artery disease. Although it is recognized that mortality figures are a poor index of the prevalence of hypertension (W.H.O., 1959), they are probably a fair index of the incidence of cerebrovascular accidents taken as a group.

\section{DATA}

The Irish data are again drawn from the annual reports of the registration of births, marriages, and deaths in the Republic of Ireland from 1926 to 1957, prepared on behalf of the Registrar General. The classification of cause of death is made in accordance with the International Statistical Classification, which has been changed three times since 1926. It proved impossible to obtain any continuity over the entire period in respect of hypertension, but some continuity has been obtainable for cerebrovascular accidents. The exact details of the list

* Present address London School of Hygiene and Tropical Medicine, Keppel Street, London, W.C.1. numbers adopted for the present study are presented in Table 1.

TABLE I

DESCRIPTION OF DISEASES CLASSIFIED AS HYPERTENSION AND CEREBROVASCULAR ACCIDENTS

\begin{tabular}{|c|c|c|}
\hline $\begin{array}{l}\text { Inter- } \\
\text { national } \\
\text { Classifi- } \\
\text { cation }\end{array}$ & Hypertension & $\begin{array}{l}\text { Cerebrovascular } \\
\text { Accidents }\end{array}$ \\
\hline $\begin{array}{l}\text { 1926-1930 } \\
\text { (Third } \\
\text { Revision) }\end{array}$ & & $\begin{array}{l}\text { 74a Cerebral Haemor- } \\
\text { rhage, Apoplexy } \\
\text { 74b Cerebral Thrombosis } \\
\text { and Embolism } \\
\text { 75a Hemiplegia }\end{array}$ \\
\hline $\begin{array}{l}\text { 1931-1939 } \\
\text { (Fourth } \\
\text { Revision) }\end{array}$ & $\begin{array}{l}102 \text { Idiopathic Abnor- } \\
\text { malities of Blood } \\
\text { Pressure }\end{array}$ & $\begin{array}{l}\text { 82a Cerebral Haemor- } \\
\text { rhage } \\
\text { b Cerebral Thrombosis, } \\
\text { Embolism } \\
\text { c Cerebral Softening } \\
\text { d Hemiplegia }\end{array}$ \\
\hline $\begin{array}{l}\text { 1940-1949 } \\
\text { (Fifth } \\
\text { Revision) }\end{array}$ & & 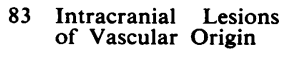 \\
\hline $\begin{array}{l}\text { 1950-1956 } \\
\text { (Sixth } \\
\text { Revision) }\end{array}$ & 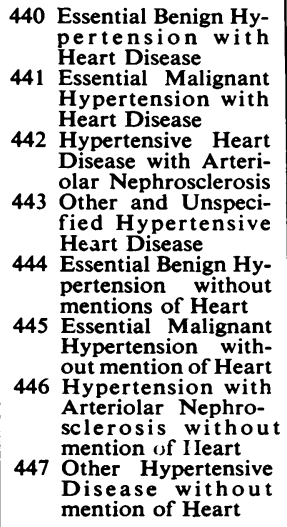 & $\begin{array}{l}331 \text { Cerebral Haemor- } \\
\text { rhage } \\
332 \text { Cerebral Embolus and } \\
\text { Thrombosis }\end{array}$ \\
\hline
\end{tabular}




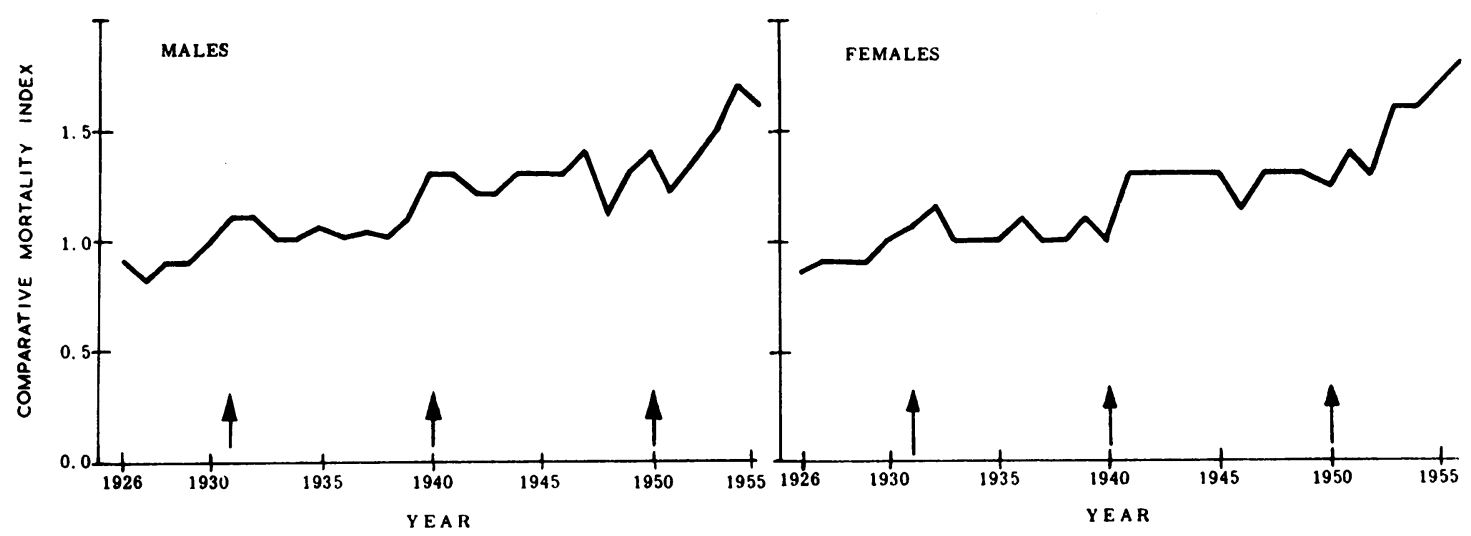

Fig. 1.-Comparative mortality indices for both sexes for cerebro-vascular accidents in the Republic of Ireland, 1926 to 1956.

It will be noted that the International List has never distinguished cerebral embolus and cerebral thrombosis, and that for the present purpose these two diagnoses have been grouped with cerebral haemorrhage.

\section{Secular Trend}

Comparative mortality indices (C.M.Is.) taking 1938 as unity, are shown for both sexes for cerebrovascular accidents in Fig. 1. There is a slight secular increase between 1926 and 1949, the index rising from 0.9 to 1.3 in both sexes. Between 1950 and 1956, however, the increase is much more rapid, rising from 1.3 to 1.8 in both sexes.

Changes in the International List have made it impossible to calculate the comparative mortality indices for hypertension. The age-specific death rates for each of the years from 1950 to 1956, however, suggest that during this time, at least, there has been little change in any but the oldest age groups where there has been more than a three-fold increase in both sexes (see Table II).

\section{Age INCIDENCE}

Age-specific death rates for cerebrovascular accidents in each of the three decades between 1926 and 1956 are shown in Table III (opposite). When the decades are compared, there has been a tendency, particularly in the post war period, for the death rates to fall in females aged under 54 and to rise in both sexes in the oldest age groups. With the exception of those
TABLE II

ANNUAL DEATHS PER 100,000 FROM HYPERTENSION, 1950-56

\begin{tabular}{|c|c|c|c|c|c|c|c|c|}
\hline Sex & $\underset{(y r s)}{\text { Age Group }}$ & 1950 & 1951 & 1952 & 1953 & 1954 & 1955 & 1956 \\
\hline Male & $\begin{array}{c}30- \\
35- \\
40- \\
45- \\
50- \\
55- \\
60- \\
65- \\
70- \\
75- \\
80- \\
85 \text { and Over }\end{array}$ & $\begin{array}{r}1 \\
7 \\
13 \\
5 \\
29 \\
63 \\
81 \\
109 \\
179 \\
186 \\
219 \\
201\end{array}$ & \begin{tabular}{r|}
2 \\
1 \\
3 \\
19 \\
33 \\
70 \\
77 \\
126 \\
190 \\
310 \\
300 \\
290
\end{tabular} & $\begin{array}{r}4 \\
2 \\
5 \\
23 \\
31 \\
46 \\
99 \\
163 \\
202 \\
303 \\
314 \\
274\end{array}$ & $\begin{array}{r}4 \\
5 \\
5 \\
9 \\
35 \\
46 \\
78 \\
110 \\
168 \\
303 \\
382 \\
328\end{array}$ & \begin{tabular}{r|}
3 \\
4 \\
13 \\
13 \\
21 \\
71 \\
98 \\
131 \\
175 \\
335 \\
382 \\
675
\end{tabular} & $\begin{array}{r}3 \\
4 \\
4 \\
7 \\
26 \\
75 \\
98 \\
170 \\
281 \\
392 \\
499 \\
675\end{array}$ & $\begin{array}{r}4 \\
10 \\
9 \\
10 \\
23 \\
66 \\
102 \\
120 \\
220 \\
424 \\
438 \\
639\end{array}$ \\
\hline Female & $\begin{array}{c}30- \\
35- \\
40- \\
45- \\
50- \\
55- \\
60- \\
65- \\
70- \\
75- \\
80- \\
85 \text { and Over }\end{array}$ & $\begin{array}{r}3 \\
2 \\
14 \\
19 \\
25 \\
47 \\
69 \\
127 \\
208 \\
234 \\
289 \\
141\end{array}$ & $\begin{array}{r}1 \\
6 \\
8 \\
9 \\
37 \\
50 \\
102 \\
155 \\
196 \\
300 \\
344 \\
319\end{array}$ & $\begin{array}{r}2 \\
2 \\
8 \\
20 \\
46 \\
39 \\
86 \\
122 \\
245 \\
360 \\
400 \\
282\end{array}$ & \begin{tabular}{r|}
3 \\
3 \\
11 \\
27 \\
30 \\
45 \\
92 \\
140 \\
190 \\
380 \\
443 \\
397
\end{tabular} & $\begin{array}{r}2 \\
2 \\
12 \\
18 \\
25 \\
55 \\
103 \\
148 \\
280 \\
346 \\
468 \\
500\end{array}$ & $\begin{array}{r}2 \\
5 \\
7 \\
14 \\
27 \\
53 \\
92 \\
153 \\
267 \\
474 \\
573 \\
794\end{array}$ & $\begin{array}{r}1 \\
4 \\
6 \\
12 \\
26 \\
42 \\
76 \\
737 \\
137 \\
271 \\
359 \\
653 \\
743\end{array}$ \\
\hline
\end{tabular}

aged 75 and over in the first decade, and in those aged 85 and over in the other two decades, there is in both sexes a steady upward gradient in death rates for each of the quinquennial age groups in each decade. Table II shows that there is also a steady upward gradient with age for mortality from hypertension.

\section{SeX Differences}

The sex ratios for each of the three decades are 
TABLE III

AVERAGE ANNUAL DEATHS PER 100,000 FROM CEREBROVASCULAR ACCIDENTS

\begin{tabular}{|c|c|c|c|c|c|c|c|c|}
\hline \multicolumn{2}{|c|}{ Sex } & Age Group (yrs) & \multicolumn{3}{|c|}{ Average Annual Death Rate } & \multicolumn{2}{|c|}{ Indices taking $1926-35$ as Unity } & \multirow{2}{*}{$\begin{array}{c}\begin{array}{c}\text { Index taking } \\
1935-45 \text { as } \\
\text { Unity }\end{array} \\
1946-55\end{array}$} \\
\hline Year & . & $\ldots \quad \ldots$ & 1926-35 & $1936-45$ & $1946-55$ & $1936-45$ & $1946-55$ & \\
\hline Male . . & . & $\begin{array}{c}\left.\begin{array}{c}35- \\
40- \\
45- \\
50- \\
55- \\
60- \\
65- \\
70- \\
75- \\
80-\end{array}\right\} \\
85 \text { and Over }\end{array}$ & $\begin{array}{r}9 \\
17 \\
27 \\
56 \\
122 \\
230 \\
281 \\
504 \\
500 \\
439\end{array}$ & $\begin{array}{r}8 \\
16 \\
33 \\
64 \\
102 \\
186 \\
322 \\
647 \\
744 \\
760\end{array}$ & \begin{tabular}{r|}
8 \\
17 \\
26 \\
58 \\
102 \\
190 \\
314 \\
536 \\
1,504 \\
1,149
\end{tabular} & $\begin{array}{l}0 \cdot 8 \\
0 \cdot 9 \\
1 \cdot 2 \\
1 \cdot 1 \\
0 \cdot 8 \\
0 \cdot 8 \\
1 \cdot 1 \\
1 \cdot 3 \\
1 \cdot 5 \\
1 \cdot 7\end{array}$ & $\begin{array}{l}0 \cdot 8 \\
1.0 \\
0.9 \\
1 \cdot 0 \\
0 \cdot 8 \\
0 \cdot 8 \\
1 \cdot 1 \\
1 \cdot 1 \\
3 \cdot 0 \\
2 \cdot 6\end{array}$ & $\begin{array}{l}1 \cdot 0 \\
1.1 \\
0.8 \\
0.9 \\
1 \cdot 0 \\
1.0 \\
1.0 \\
0.8 \\
2 \cdot 0 \\
1 \cdot 5\end{array}$ \\
\hline Female & $\cdots$ & $\begin{array}{c}\left.\begin{array}{c}35- \\
40- \\
45- \\
50- \\
55- \\
60- \\
65- \\
70- \\
75- \\
80\end{array}\right\} \\
85 \text { and Over }\end{array}$ & $\begin{array}{r}15 \\
29 \\
56 \\
107 \\
168 \\
291 \\
359 \\
533 \\
532 \\
437\end{array}$ & $\begin{array}{r}14 \\
33 \\
54 \\
112 \\
167 \\
293 \\
435 \\
688 \\
806 \\
815\end{array}$ & $\begin{array}{r}11 \\
17 \\
42 \\
89 \\
142 \\
256 \\
379 \\
622 \\
1,595 \\
1,226\end{array}$ & $\begin{array}{l}0 \cdot 9 \\
1 \cdot 2 \\
1 \cdot 0 \\
1 \cdot 0 \\
1 \cdot 0 \\
1 \cdot 0 \\
1 \cdot 2 \\
1 \cdot 3 \\
1 \cdot 5 \\
1 \cdot 9\end{array}$ & $\begin{array}{l}0.7 \\
0.6 \\
0.7 \\
0.8 \\
0.8 \\
0.9 \\
1.1 \\
1.2 \\
3 \cdot 0 \\
2.8\end{array}$ & $\begin{array}{l}0.7 \\
0.5 \\
0.8 \\
0.8 \\
0.8 \\
0.9 \\
0.9 \\
0.9 \\
2.0 \\
1.5\end{array}$ \\
\hline
\end{tabular}

shown by quinquennial age groups for cerebrovascular accidents in Table IV. At all ages and at all times this has been a commoner certified cause of death in females than in males. The sex difference is most marked in the youngest groups and becomes steadily less until the ratio approaches unity in the oldest groups. There is remarkably little secular trend in the sex ratio at any age group.

TABLE IV

SEX RATIO (M/F) FOR CEREBROVASCULAR ACCIDENTS IN IRELAND, BY AGE GROUP AND DECADE, 1926-55

\begin{tabular}{c|c|c|c}
\hline \multirow{2}{*}{$\begin{array}{c}\text { Age Group } \\
\text { (yrs) }\end{array}$} & \multicolumn{3}{c}{ Decade } \\
\cline { 2 - 4 } & $1926-1935$ & $1936-1945$ & $1946-1955$ \\
\hline $35-$ & 0.6 & 0.5 & 0.7 \\
$40-$ & 0.6 & 0.5 & 1.0 \\
$45-$ & 0.5 & 0.6 & 0.6 \\
$50-$ & 0.5 & 0.6 & 0.6 \\
$55-$ & 0.7 & 0.6 & 0.7 \\
$60-$ & 0.8 & 0.6 & 0.7 \\
$65-$ & 0.8 & 0.7 & 0.8 \\
$70-$ & 0.9 & 0.9 & 0.9 \\
75 & 0.9 & 0.9 & 0.9 \\
$80\}$ & 1.0 & 0.9 & 0.9 \\
85 and Over & & & \\
\hline
\end{tabular}

Table $\mathrm{V}$ shows the sex ratios for hypertension for the period during which comparable statistics are available; with the exception of the youngest groups, where the death rates are very low, and the groups aged 55-64, hypertension also seems to be a commoner certified cause of death in females than in males, but there is no comparable tendency for the ratio to increase with age.
TABLE V

SEX RATIO (M/F) FOR HYPERTENSION IN IRELAND, BY AGE GROUP, 1950-56

\begin{tabular}{c|c}
\hline Age Group (yrs) & $1950-1956$ \\
\hline $30-$ & 1.5 \\
$35-$ & 1.7 \\
$40-$ & 0.8 \\
$45-$ & 0.7 \\
$50-$ & 0.9 \\
$55-$ & 1.3 \\
$60-$ & 1.0 \\
$65-$ & 0.9 \\
$70-$ & 0.8 \\
$75-$ & 0.9 \\
$80-$ & 0.8 \\
85 and Over & 1.0
\end{tabular}


Geographical Differences Within the Republic OF IRELAND

Death rates for the period 1951 to 1955 standardized to the population in 1951 for the counties and county boroughs in the Republic are shown in Table VI and Fig. 2, and in Figs 3 and 4 (opposite).

\section{TABLE VI}

AVERAGE ANNUAL DEATH RATES PER 100,000 (AT AGE 35+) FOR COUNTIES AND BOROUGHS, 1951-1955 STANDARDIZED TO THE POPULATION IN 1951, BY SEX

\begin{tabular}{|c|c|c|c|c|c|c|c|c|}
\hline \multicolumn{2}{|c|}{ Cause of Death } & \multirow{2}{*}{$\begin{array}{l}\cdots \\
\ldots\end{array}$} & \multirow{2}{*}{. } & \multirow{2}{*}{$\begin{array}{l}\cdots \\
\cdots \\
\\
\end{array}$} & \multicolumn{2}{|c|}{$\begin{array}{l}\text { Cerebro- } \\
\text { vascular } \\
\text { Accidents }\end{array}$} & \multicolumn{2}{|c|}{$\begin{array}{l}\text { Hyper- } \\
\text { tension }\end{array}$} \\
\hline Sex & . & & & & Male & $\begin{array}{l}\text { Fe- } \\
\text { male }\end{array}$ & Male & $\begin{array}{c}\text { Fe- } \\
\text { male }\end{array}$ \\
\hline Counties & $\begin{array}{l}1 . \\
2 . \\
3 . \\
4 . \\
5 . \\
6 . \\
7 . \\
8 . \\
9 . \\
10 . \\
11 . \\
12 . \\
13 . \\
14 . \\
15 . \\
16 . \\
17 . \\
18 . \\
19 . \\
20 . \\
21 . \\
22 . \\
23 . \\
24 . \\
25 . \\
26 . \\
27 .\end{array}$ & $\begin{array}{l}\text { rlow } \\
\text { van } \\
\text { ire } \\
\text { rk } \\
\text { negal } \\
\text { blin } \\
\text { lway } \\
\text { rry } \\
\text { dare } \\
\text { kenny } \\
\text { oghis } \\
\text { trim } \\
\text { nerick } \\
\text { ngford } \\
\text { uth } \\
\text { yo } \\
\text { ath } \\
\text { naghan } \\
\text { aly } \\
\text { scommo } \\
\text { so } \\
\text { perary, } \\
\text { perary, } \\
\text { terford } \\
\text { stmeath } \\
\text { exford } \\
\text { cklow }\end{array}$ & 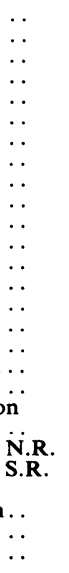 & 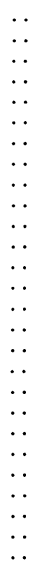 & $\begin{array}{l}182 \\
182 \\
144 \\
192 \\
211 \\
155 \\
153 \\
147 \\
130 \\
161 \\
191 \\
199 \\
124 \\
117 \\
184 \\
110 \\
194 \\
157 \\
173 \\
142 \\
191 \\
208 \\
218 \\
178 \\
185 \\
242 \\
307\end{array}$ & $\begin{array}{l}159 \\
266 \\
179 \\
245 \\
225 \\
199 \\
188 \\
203 \\
216 \\
194 \\
268 \\
259 \\
187 \\
107 \\
254 \\
132 \\
243 \\
254 \\
243 \\
182 \\
192 \\
223 \\
260 \\
290 \\
281 \\
303 \\
369\end{array}$ & $\begin{array}{r}83 \\
107 \\
45 \\
55 \\
50 \\
87 \\
82 \\
88 \\
39 \\
80 \\
70 \\
61 \\
53 \\
84 \\
55 \\
62 \\
103 \\
68 \\
78 \\
74 \\
78 \\
74 \\
56 \\
43 \\
79 \\
82 \\
109\end{array}$ & $\begin{array}{r}64 \\
126 \\
49 \\
69 \\
59 \\
126 \\
72 \\
89 \\
61 \\
88 \\
89 \\
68 \\
82 \\
61 \\
48 \\
78 \\
96 \\
94 \\
73 \\
91 \\
96 \\
76 \\
86 \\
72 \\
74 \\
75 \\
94\end{array}$ \\
\hline Boroughs & $\begin{array}{l}28 . \\
29 . \\
30 . \\
31 . \\
32 .\end{array}$ & $\begin{array}{l}\text { k C.B. } \\
\text { olin C.B } \\
\text { Laogh } \\
\text { erick C } \\
\text { terford }\end{array}$ & $\begin{array}{l}\text { B. } \\
\text { haire C } \\
\text { C.B. } \\
\text { C.B. }\end{array}$ & & $\begin{array}{l}224 \\
209 \\
286 \\
141 \\
194\end{array}$ & $\begin{array}{l}255 \\
231 \\
332 \\
143 \\
275\end{array}$ & $\begin{array}{r}76 \\
120 \\
140 \\
60 \\
38\end{array}$ & $\begin{array}{r}80 \\
136 \\
135 \\
52 \\
48\end{array}$ \\
\hline \multicolumn{3}{|c|}{ Republic of Ireland } & & & 182 & 226 & 77 & 90 \\
\hline
\end{tabular}

Although it might be maintained that the urban death rate from cerebrovascular accidents is on the average a little higher than the rural death rate from this cause, and that death rates in the south-east are higher than those in the north-west, there is no very strongly defined geographical pattern, nor is there a very wide range of variation. The highest death rate ( 369 for women in County Wicklow) is only three and a half times higher than the lowest (107 for women in County Longford). In the case of hypertension, although the rates are on the whole much lower, the range of variation is much the same, the rate of 140 for males in Dun Laoghaire being 3.7 times higher than the rate of $\mathbf{3 8}$ for males in Waterford County Borough; but the overall pattern seems to be even less clearly defined.

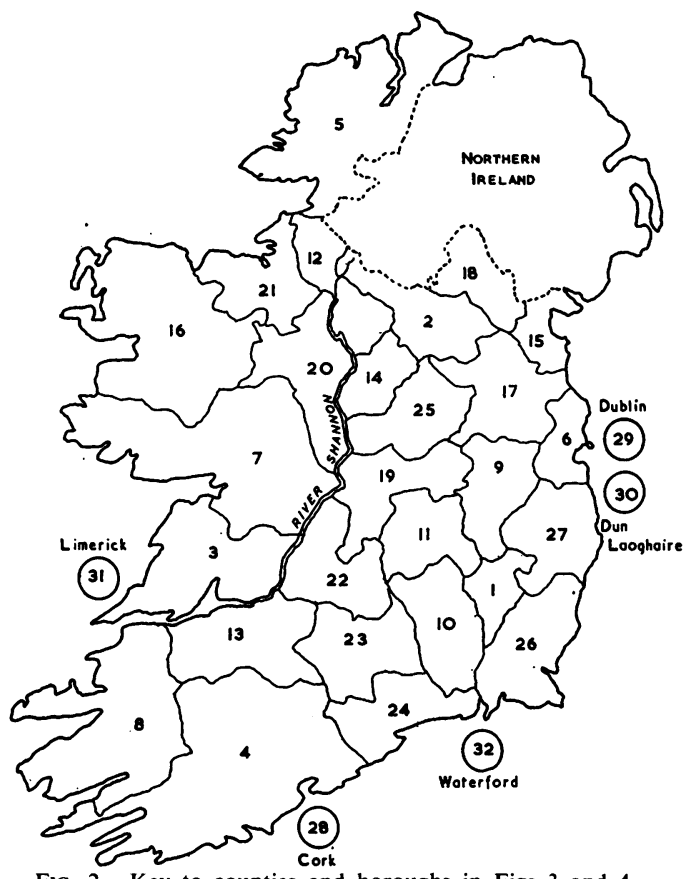

Fig. 2.-Key to counties and boroughs in Figs 3 and 4.

OCCUPATION AND INCOME

Causes of death are not published by trade and occupation in the Republic because the necessary social classification offers considerable technical difficulties. It has not therefore been possible to analyse the present data in terms of social status or occupational hazard.

COMPARISON OF MORTALITY FROM CEREBRovascular ACCIDENTS AND HYPERTENSION IN THE REPUBLIC OF

IRELAND WITH THAT IN OTHER COUNTRIES

Tables VII and VIII (overleaf) show death rates for the two groups for various countries in 1955, standardized against the Irish population in 1951, the countries being ranked in order of the male death rates. Three aspects of these Tables are worthy of comment; first, the lowest death rate from cerebrovascular accidents is considerably higher than the highest death rate ascribed to hypertension; secondly, although the sex ratio for cerebrovascular accidents does not range appreciably from unity for any of the countries, if the countries had been ranked according to female death rates the order would change a great deal-for example, Sweden would rise from eleventh to fourth position, and France would fall from eighth to fifteenth. In the case of hypertension it is also true that the order of ranking by female death rates would be quite different from that by male death rates, but this is 


\section{CEREBROVASCULAR DISEASE}

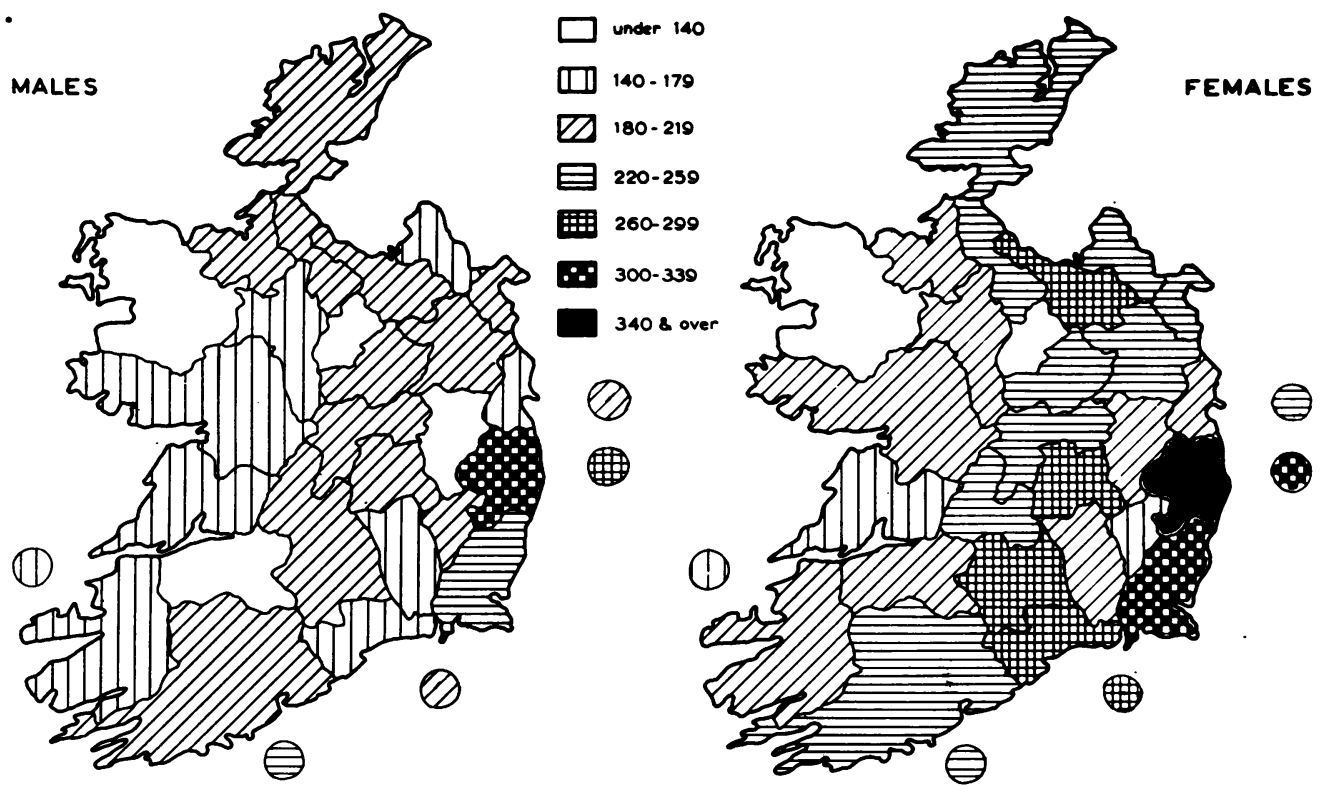

Fig. 3.-Average annual death rates, 1951-1955, from cerebrovascular disease, by counties and boroughs (see also Table VI). The scheme used for shading is the same for both sexes.

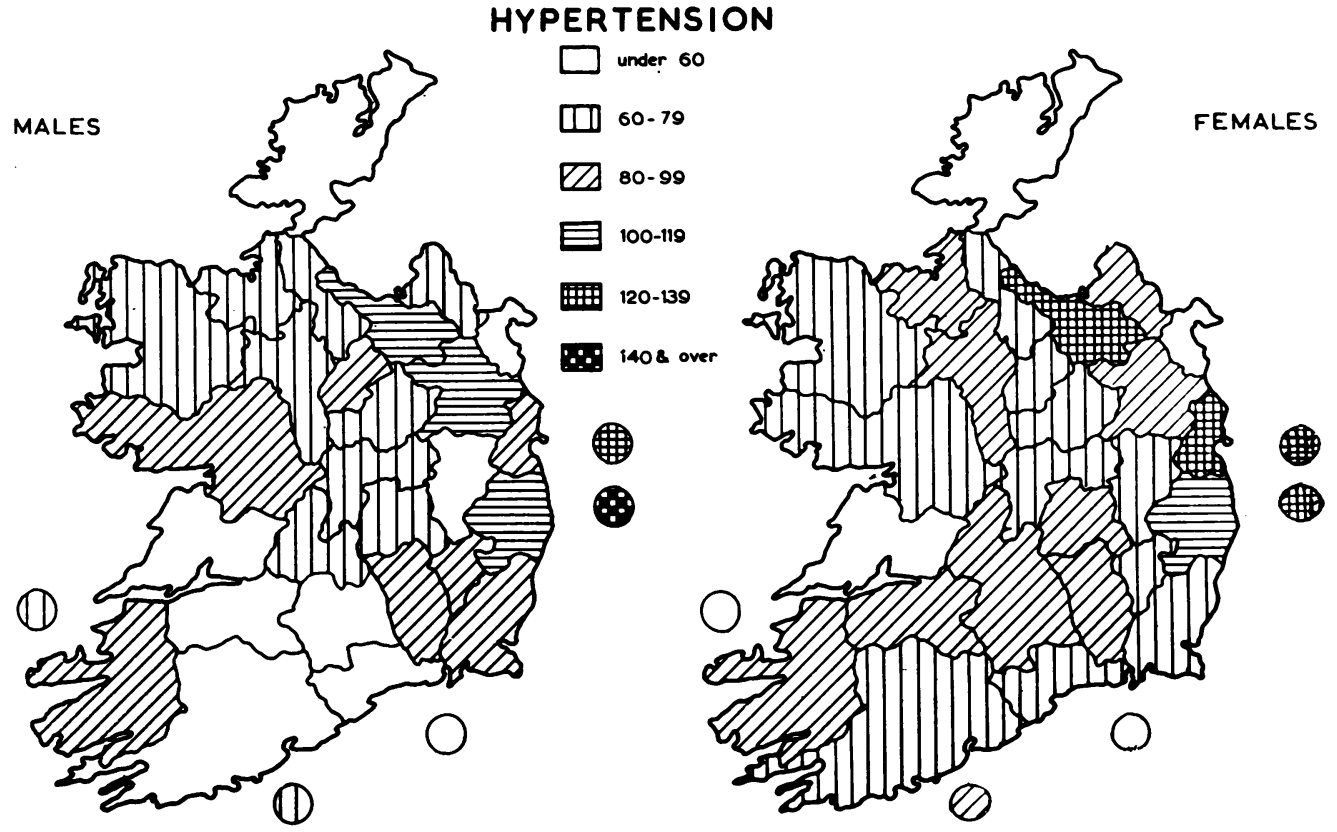

FIG. 4.-Average annual death rates, 1951-1955, from hypertension by counties and boroughs (see also Table VI). The scheme used for shading is the same for both sexes. 
less surprising because the sex ratio varies rather more widely than in Table VII and there is very little difference between the male rates for the first nine countries.

TABLE VII

DEATH RATES PER 100,000 FROM CEREBROVASCULAR DISEASE (AT AGE 40+) FOR VARIOUS COUNTRIES IN 1955 (STANDARDIZED TO IRISH POPULATION, 1951)

\begin{tabular}{|c|c|c|c|}
\hline \multirow{2}{*}{ Country } & \multicolumn{2}{|c|}{ Sex } & \multirow{2}{*}{ Ratio $\mathbf{M} / \mathbf{F}$} \\
\hline & Male & Female & \\
\hline 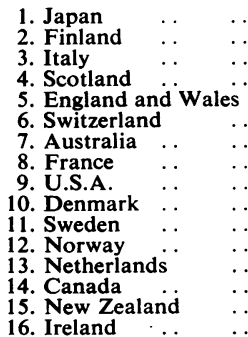 & $\begin{array}{l}774 \\
476 \\
465 \\
440 \\
421 \\
393 \\
378 \\
378 \\
342 \\
338 \\
331 \\
324 \\
319 \\
318 \\
294 \\
250\end{array}$ & $\begin{array}{l}611 \\
511 \\
413 \\
538 \\
412 \\
402 \\
428 \\
307 \\
336 \\
386 \\
478 \\
371 \\
380 \\
343 \\
395 \\
301\end{array}$ & $\begin{array}{l}1.3 \\
0.9 \\
1.1 \\
0.8 \\
1.0 \\
1.0 \\
0.9 \\
1.2 \\
1.0 \\
0.9 \\
0.7 \\
0.9 \\
0.8 \\
0.9 \\
0.8 \\
0.8\end{array}$ \\
\hline
\end{tabular}

TABLE VIII

DEATH RATES PER 100,000 FROM HYPERTENSION (AT AGE 40+) FOR VARIOUS COUNTRIES IN 1955 (STANDARDIZED TO IRISH POPULATION, 1951)

\begin{tabular}{|c|c|c|c|}
\hline \multirow{2}{*}{ Country } & \multicolumn{2}{|c|}{ Sex } & \multirow{2}{*}{ Ratio $M / F$} \\
\hline & Male & Female & \\
\hline 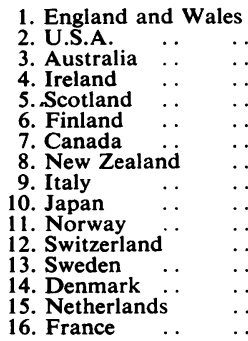 & $\begin{array}{l}128 \\
120 \\
118 \\
112 \\
112 \\
104 \\
104 \\
101 \\
93 \\
61 \\
60 \\
56 \\
56 \\
51 \\
39 \\
23\end{array}$ & $\begin{array}{l}109 \\
172 \\
125 \\
120 \\
107 \\
196 \\
136 \\
129 \\
109 \\
53 \\
68 \\
81 \\
76 \\
77 \\
62 \\
20\end{array}$ & $\begin{array}{l}1 \cdot 2 \\
0.7 \\
0.9 \\
0.9 \\
1 \cdot 0 \\
0.5 \\
0.8 \\
0.8 \\
0 \cdot 8 \\
1.1 \\
0.9 \\
0 \cdot 7 \\
0 \cdot 7 \\
0 \cdot 7 \\
0 \cdot 6 \\
1 \cdot 1\end{array}$ \\
\hline
\end{tabular}

Correlation Between Deaths for Cerebrovascular ACCIDENTS, Hypertension, AND

Coronary ARTERY Disease

In order to investigate further the interrelationships between the mortality patterns of the two diseases being studied here and that of coronary artery disease, a correlation analysis was carried out between the standardized death rates shown in Tables VI, VII and VIII above and those in Tables IV and VI in the earlier publication (Acheson and Thornton, 1958). The results are given in Tables IX, X, and XI.

Table IX shows that, despite the variations in sex ratio referred to above, the mortality in the two sexes for each of the three diseases is highly correlated both inside Ireland and in the comparison between Ireland and other countries. The correlations tend to be higher in the international comparison than inside Ireland, but in each case they are highest for coronary artery disease. The crosscorrelations between the three diseases inside Ireland are given in Table $X$ which shows that all the correlations for males are higher than those for females; in females the highest correlation is that between coronary artery disease and hypertension, and the male correlation between these two diseases is also high. However, the correlations between the other diseases for both sexes are positive, and (with the exception of those shown between cerebrovascular accidents and hypertension for females) they are significant at the 5 per cent. level at the least.

\section{TABLE IX}

CORRELATION BETWEEN MALE AND FEMALE STANDARDIZED DEATH RATES FOR THE 32 IRISH COUNTIES AND FOR THE 16 COUNTRIES SHOWN IN TABLES VII AND

\begin{tabular}{ll|c|c}
\hline Cause of Death & $\begin{array}{c}\text { 32 Irish Counties } \\
\text { and Boroughs, } \\
1951-1955\end{array}$ & $\begin{array}{c}16 \text { Countries } \\
\text { shown in Tables } \\
\text { VII and VIII }\end{array}$ \\
\hline $\begin{array}{ll}+0.75 \\
+0.80 \\
+0.83\end{array}$ & $\begin{array}{r}+0.87 \\
+0.79 \\
+0.94\end{array}$ \\
\hline $\begin{array}{l}\text { Cerebrovascular Disease } \\
\text { Coronary Artery Disease }\end{array}$ & $\cdots$ & \begin{aligned} 0.9 \\
\hline\end{aligned}
\end{tabular}

TABLE X

CORRELATION BETWEEN STANDARDIZED DEATH RATES FROM THREE DISEASES IN IRELAND

\begin{tabular}{|c|c|c|}
\hline Variables & Male & Female \\
\hline $\begin{array}{ccccc}\text { Coronary Artery Disease and Hyper- } \\
\text { tension } & . & \ldots & . . & .\end{array}$ & $+0 \cdot 57^{* * * *}$ & $+0.42^{* *}$ \\
\hline $\begin{array}{ccc}\text { Coronary Artery Disease and Cere- } \\
\text { brovascular Disease } & . . & . .\end{array}$ & $+0 \cdot 58^{* * * *}$ & $+0.35^{*}$ \\
\hline $\begin{array}{c}\text { Cerebrovascular Disease and Hyper- } \\
\text { tension } \quad \ldots \\
\text {. . }\end{array}$ & $+0.47^{* * *}$ & $+0 \cdot 27$ \\
\hline
\end{tabular}

TABLE XI

CORRELATION BETWEEN STANDARDIZED DEATH RATES FROM THREE DISEASES IN 16 COUNTRIES (SEE TABLES VII AND VIII)

\begin{tabular}{|c|c|c|}
\hline Variables & Male & Female \\
\hline $\begin{array}{ccc}\text { Coronary Artery Disease (1954) } & \text { and } \\
\text { Hypertension (1955) } & \ldots & \ldots\end{array}$ & $+0.67^{* * *}$ & $+0.63^{* * *}$ \\
\hline $\begin{array}{l}\text { Coronary Artery Disease (1954) and } \\
\text { Cerebrovascular Disease (1955) } \ldots\end{array}$ & -0.42 & $-0 \cdot 20$ \\
\hline $\begin{array}{ccc}\text { Cerebrovascular Disease } & (1955) & \text { and } \\
\text { Hypertension (1955) } & \ldots & \ldots\end{array}$ & -0.07 & +0.01 \\
\hline
\end{tabular}

The international analyses (see Table XI) also show that the highest correlation in both sexes is that between coronary artery disease and hypertension. Beyond this, however, there is little further 
similarity between Tables $\mathrm{X}$ and $\mathrm{XI}$, for the international analysis fails to demonstrate any correlation between cerebrovascular accidents and hypertension for either sex, and such correlation as exists between cerebrovascular disease and coronary artery disease is negative, whereas in Ireland it is positive.

\section{Discussion}

Before attempting to evaluate the positive findings made in this study, the shortcomings of the data should be stressed. Cerebrovascular accidents most commonly involve the middle cerebral artery, and result in hemiparesis or hemiplegia. Of all causes of death, apoplexy with hemiplegia is probably the easiest to distinguish. and therefore carries the least observer error in certification. Yet this apparent simplicity in diagnosis is most deceptive because, while the classical apoplexy is usually caused by haemorrhage, the haemorrhage may be into the brain stem, or the lesion may be due to a thrombus of any of a number of arteries. Furthermore, an almost identical clinical picture may develop as a consequence of embolism, a lesion of quite distinct aetiology from haemorrhage or thrombosis. The arrangement of the International List has made it impossible to distinguish between the three, partly because, throughout the period studied, cerebral thrombosis and cerebral embolism have always been grouped together, and partly because between 1926 and 1939 the supplementary heading of hemiplegia was offered. Thus, under the heading of cerebrovascular accidents, we are really considering three distinct diseases which may produce a single clinical pattern; the latter misleadingly obvious to doctor and layman alike.

Hypertension, on the other hand, can be diagnosed with certainty in the home (where most deaths occur) only by the use of a sphygmomanometer while the patient is alive. Very often, moreover, there is a fall in blood pressure in agonal heart failure, so that a doctor attending the last illness may not realize that the blood pressure was previously raised, with the result that death is ascribed to "cardiac failure" or "myocardial degeneration" without any mention of hypertension. Thus, many hundreds of deaths which were in fact due to hypertension must appear among the 4,965 classified as caused by "other myocardial degeneration" (Int. List No. 422) out of a total of 10,902 cardiac deaths in the Republic of Ireland in 1956.

A further difficulty stems from the fact that, even in cases in which the hypertension has been recognized, it may be listed on the death certificate as a contributary cause of death, or as a complication, rather than as the disease which is really responsible for death. In many countries, therefore, it will not appear in the national vital statistics. Broderick (1955), in a detailed analysis of death certificates in the county borough of Dublin, has shown that this is indeed the case. During the year 1952 a total of 310 deaths was certified as due to hypertension (Int. List Nos. 440-447). In a further 386 certificates, however, hypertension appeared as a complication or as a contributary cause of death. In 134 of these cases cerebral haemorrhage (Int. List No. 331) was certified as being the underlying disease directly responsible for death and in 102 cases coronary artery disease (Int. List No. 420). On the one hand, this evidence indicates that the published mortality from hypertension underestimates the prevalence of the disease by a factor of two at least; on the other hand, it amply supports the statement made at the beginning of this paper that cerebral vascular disease and coronary artery disease are commonly complicated by hypertension. Thus, statistics compiled from death certificates will tend to underestimate the prevalence of hypertension.

A further complication is that the degree of underestimation of the prevalence of hypertension will vary from place to place depending, among other things, on the national laws and practices concerning the completion of the death certificate and the coding of the cause of death. These in turn will depend on the medical tradition in the schools where the doctors were trained, on their knowledge of the methods of their national departments of vital statistics, and on their understanding of the importance of imparting accurate standardized information. National differences will depend too upon the extent to which the authorities confine their interest in the death certificate solely to the ruling out of foul play and how much to the compilation of accurate mortality statistics. W.H.O. has attempted to do away with such idiosyncrasies by drawing up a standard form of death certificate and by publishing a manual of rules for abstracting information from certificates on which several causes of death appear (W.H.O., 1948). Both of these are used by many member countries, including Ireland. Other matters of importance are the proportion of the population which dies in hospital, and the amount the doctor certifying the death knows about his patient. It is, therefore, perhaps a little incongruous that the International List should offer six sub-groups for the classification of hypertension which may require the diagnostic facilities of a hospital for their identification, and yet should fail to separate cerebral embolism and thrombosis which can often be distinguished by careful history-taking. 
The findings in the present analysis will have to be considered, these shortcomings being borne in mind. If it is accepted that the rise in comparative mortality indices for cerebrovascular disease in the Republic of Ireland in both sexes in 1931, 1940, and 1950 are due to changes in the International List, the most striking characteristic of Figs 1 and 2 is the extraordinary steadiness of these indices between 1926 and 1950. During the final 6 years, however, there can be little doubt that a genuine rise has taken place. Much if not all of this rise is probably due to improvement in the collection of statistics. During this time there has been a drive in the more rural and isolated parts of the Republic to ensure that all deaths are properly certified, with the result that there has been a very sharp fall in the numbers of deaths ascribed to senility or remaining uncertified (for further details see Acheson and Thornton, 1958). This trend is also reflected in Tables II and III, where the apparent rise in death rates from hypertension as well as from cerebrovascular disease among the older age groups must also be largely, if not entirely, due to more accurate certification.

The secular fall in the death rate from cerebrovascular accidents in women aged $35-54$ is more likely to be real. One possible cause of this is the decrease in the number of cases of rheumatic heart disease, a decrease which is reflected in the fact that the death rates from this cause in Ireland have been almost halved during the 30 years under consideration. Therefore, deaths from cerebral embolism have presumably fallen too, because cerebral embolism is very often associated with rheumatic carditis, and is more likely to develop in young women than in old people of either sex. The available statistics are not, however, suitable for examining this hypothesis in any detail.

The most interesting aspect of the geographical data is the correlation analysis shown in Tables IX to XI. Evidently there is no great discrepancy in Ireland, or in the other countries studied, between death rates in the two sexes, for the between sex correlations vary from 0.75 to 0.94 . The value of 0.94 for coronary artery disease can be interpreted as giving indirect supportive evidence for the conclusion, drawn from the Irish comparative mortality indices (Acheson and Thornton, 1958), that the rate of increase in female death rates from this disease has been as rapid as that in male death rates. It can also be looked upon as a reflection of the accuracy of diagnosis, however, for Tables X and $\mathrm{XI}$ show that the only consistently high correlations are those between coronary artery disease and hypertension. It could well be argued that a similar type of modus vivendi or environment is a contributory factor to causing death from the two diseases. On the other hand, these diseases require refined medical techniques for their diagnosis, and the observed correlation may really reflect the standard of medical care. In the previous paper (Acheson and Thornton, 1958), it was concluded that the increase in mortality from coronary artery disease was not entirely attributable to improved diagnostic methods. This is not to say, however, that the level of medical skill in a community has no bearing on the certified death rate from coronary artery disease; it certainly must have some bearing, as indeed it must on the certified death rate from hypertension. Furthermore, as Tables VI, VII, and VIII show, the geographical areas both inside and outside Ireland with the highest mortality from these causes tend to be those with the most highly developed medical services; thus, although the social culture which Morris (1955) has dubbed the "Western" way of life may cause people to die from hypertension, as it is known to cause them to die from coronary artery disease, the statistical relationship found between the death rates from the two causes in the present study is more than likely to be also a reflection of diagnosis and certification.

There is a wide difference in the correlation between cerebrovascular disease and hypertension or coronary disease shown in Table $\mathrm{X}$ as compared with that shown in Table XI. In Ireland the areas with high death rates for one of the three certified causes of death tend to have high death rates for the other two, particularly in males. In the international comparison this is clearly not the case, the most striking difference being that Japanese males show the highest standardized death rate for cerebrovascular disease and the lowest for coronary artery disease (see Acheson and Thornton, 1958). While such discrepancies between one country and another may to some extent be due to true differences in the epidemiology of disease, variations in diagnostic and statistical technique cannot be ruled out as an important contributary factor.

Few facts of epidemiological value have resulted from this analysis. It does, however, illustrate admirably the pressing need (stated by W.H.O. 1959) for a thorough scientific study of the methods whereby vital statistics are collected all over the world.

\section{SUMMARY}

(1) Between 1926 and 1956 comparative mortality indices for both sexes in the Republic of Ireland show a rise for cerebrovascular accidents. This is probably entirely due to changes in the International Classification of Causes of Death and to more 
accurate certification of death. A similar study of the secular trend in mortality from hypertension was impossible because of alterations in the International List; between 1950 and 1956 however, there was no suggestion of consistent change, except in the oldest groups where death rates rose but certification has improved.

(2) Both cerebrovascular accidents and hypertention were more commonly certified as causing death in women than in men.

(3) In respect of cerebrovascular disease, the average standardized death rates for the period 1950-1955 tended to be higher in urban than in rural districts; they also tended to be higher in the counties of the eastern seaboard than elsewhere in the rural parts of the Republic. For hypertension the average standardized death rates for the conurbation of Dublin were higher than those elsewhere in the Republic; otherwise there was little consistent geographical pattern.

(4) Of sixteen countries whose vital statistics are regularly published by W.H.O., Ireland in 1955 had the fourth highest male death rate from hypertension but the lowest from cerebrovascular accidents-all death rates being standardized to the Irish population in 1951.

(5) A correlation analysis was carried out between death rates for hypertension, cerebrovascular accidents, and coronary artery disease for the 32 administrative areas inside Ireland and for Ireland and the other fifteen countries, with the following results:

(a) There were high positive correlations between the sexes for all three diseases, the highest correlation in each analysis being that for coronary heart disease $(+0.83$ in Ireland and +0.94 in the International comparison). (b) There was a highly significant correlation between hypertension and coronary artery disease both inside Ireland and internationally.

(c) Inside Ireland the other correlations were positive, and the only one which was not significant was that between cerebrovascular accidents and hypertension for females.

(d) In the international comparison, correlations between cerebrovascular accidents and hypertension differed little from zero, and those between coronary artery disease and cerebrovascular disease were negative.

(6) In considering the possible significance of these findings, the grave shortcomings of mortality figures for cerebrovascular accidents and hypertension as a basis for epidemiological studies are stressed.

I am most grateful to Miss Marie Geoghegan who bore the brunt of the computing; to Dr. Donal MacCarthy and Mr. J. F. Knaggs of the Central Statistics Office, Dublin for making available unpublished data; and to Prof. W. J. E. Jessop for encouragement. Prof. W. S. Walton kindly read the text. The research was supported by a grant from the Medical Research Council of Ireland.

\section{REFERENCES}

Acheson, R. M., and Thornton, E. H. (1958). Brit. J. prev. soc. med.,

$12,82$.
Broderick. J. B. (1955). "Classification of Multiple Causes of Death". Unpublished report to W.H.O. National Committees on Vital and Health Statistics.

Department of Health, Ireland (1955, 1957). "Reports on Vital Statistics for 1953 and 1954". Central Statistics Office, Dublin. (1946-1954). "Annual Reports of the Registrar-General for the Years, 1945-1952". Central Statistics Office, Dublin.

Department of Local Government and Public Health, Ireland (19271945). "Annual Reports of the Registrar-General for the Years 1926-1944". Central Statistics Office, Dublin.

Morris, J. N. (1955). Med. Offr., 94, 251.

Worris, Health Organization (1948). "Manual of the International

World Health Organization (1948). "Manual of the International
Statistical Classification of Diseases, Injuries, and Causes of Death", Statistical Classification of Disea
vol. 1, p. 368. W.H.O.. Geneva.

(1956). Epidem. vital Statist. Rep., 9, 582.

W (1958). "Annual Epidemiological and Vital Statistics, 1955". W.H.O., Geneva.

_- (1959). Wld Hith Org. Tech. Rep. Ser., No. 168. W.H.O., Geneva. 